\title{
Sampling harmful benthic dinoflagellates: Comparison of artificial and natural substrate methods
}

\author{
Patricia A. Tester ${ }^{a, *}$, Steven R. Kibler ${ }^{a}$, William C. Holland ${ }^{a}$, Gires Usup ${ }^{b}$, \\ Mark W. Vandersea ${ }^{a}$, Chui Pin Leaw ${ }^{c}$, Lim Po Teen ${ }^{\mathrm{d}}$, Jacob Larsen ${ }^{\mathrm{e}}$, \\ Normawaty Mohammad-Noor ${ }^{\mathrm{f}}$, Maria A. Faust ${ }^{\mathrm{g}}, \mathrm{R}$. Wayne Litaker ${ }^{\mathrm{a}}$ \\ ${ }^{a}$ National Oceanic and Atmospheric Administration, National Ocean Service, National Centers for Coastal Ocean Science, \\ Center for Coastal Fisheries and Habitat Research, 101 Pivers Island Road, Beaufort, NC 28516, USA \\ b Program Sains Laut, Pusat Pengajian Sains Sekitaran dan Sumber Alam, Fakulti Sains dan Teknologi, Universiti Kebangsaan Malaysia, \\ 43600 Bangi Selangor, Malaysia \\ ${ }^{\mathrm{c}}$ Institute of Biodiversity and Environmental Conservation, Universiti Malyasia Sarawak, 94300 Kota Samarahan, Sarawak, Malaysia \\ ${ }^{\mathrm{d}}$ Aquatic Sciences Program, Faculty of Resource Science and Technology, Universiti Malaysia Sarawak, 94300 Kota Samarahan, Sarawak, Malaysia \\ e IOC Science and Communication Centre on Harmful Algae, Department of Phycology and Mycology, Øster Farimagsgade 2D, DK-1353 Copenhagen K, Denmark \\ ${ }^{\mathrm{f}}$ Institute of Oceanography and Maritime Studies, Kulliyyah of Science, International Islamic University Malaysia, Jalan Sultan Ahmad Shah, Bandar Indera \\ Mahkota, 25200 Kuantan, Pahang, Malaysia \\ ${ }^{\mathrm{g}}$ Department of Botany, National Museum of Natural History, Smithsonian Institution, Washington, DC 20560, USA
}

\section{A R T I C L E I N F O}

\section{Article history:}

Received 14 March 2014

Received in revised form 17 June 2014

Accepted 17 June 2014

Available online 5 July 2014

\section{Keywords:}

Gambierdiscus

Ciguatera fish poisoning

Ostreopsis

Prorocentrum

Cell-based monitoring

\begin{abstract}
A B S T R A C T
This study compared two collection methods for Gambierdiscus and other benthic harmful algal bloom (BHAB) dinoflagellates, an artificial substrate method and the traditional macrophyte substrate method. Specifically, we report the results of a series of field experiments in tropical environments designed to address the correlation of benthic dinoflagellate abundance on artificial substrate and those on adjacent macrophytes. The data indicated abundance of BHAB dinoflagellates associated with new, artificial substrate was directly related to the overall abundance of BHAB cells on macrophytes in the surrounding environment. There was no difference in sample variability among the natural and artificial substrates. BHAB dinoflagellate abundance on artificial substrates reached equilibrium with the surrounding population within $24 \mathrm{~h}$. Calculating cell abundance normalized to surface area of artificial substrate, rather than to the wet weight of macrophytes, eliminates complications related to the mass of different macrophyte species, problems of macrophyte preference by BHAB dinoflagellates and allows data to be compared across studies. The protocols outlined in this study are the first steps to a standardized sampling method for BHAB dinoflagellates that can support a cell-based monitoring program for ciguatera fish poisoning. While this study is primarily concerned with the ciguatera-associated genus Gambierdiscus, we also include data on the abundance of benthic Prorocentrum and Ostreopsis cells.
\end{abstract}

(C) 2014 Elsevier B.V. All rights reserved.

\section{Introduction}

The resurgence of interest in the biodiversity of harmful benthic dinoflagellates, most notably the ciguatera-associated genus

\footnotetext{
* Corresponding author at: Center for Coastal Fisheries and Habitat Research, National Centers for Coastal Ocean Science, National Ocean Service, NOAA, 101 Pivers Island Road, Beaufort, NC 28516, USA. Tel.: +1 252728 8792; fax: +1 2527284537 .

E-mail addresses: Patricia.Tester@noaa.gov, ocean.tester@yahoo.com (P.A. Tester), Steve.Kibler@noaa.gov (S.R. Kibler), Chris.Holland@noaa.gov (W.C. Holland), Gires@ukm.my (G. Usup), Mark.W.Vandersea@noaa.gov (M.W. Vandersea), Leawcp@ibec.unimas.my (C.P. Leaw), Ptlim@frst.unimas.my (L.P. Teen), Jacob@bot.ku.dk (J. Larsen), Normahwaty@iium.edu.my (N. Mohammad-Noor), FaustM@si.edu (M.A. Faust), Wayne.Litaker@noaa.gov (R.W. Litaker).
}

Gambierdiscus (Fraga et al., 2011; Nishimura et al., 2013; Tester et al., 2013) has been facilitated by recent advances in taxonomy (Litaker et al., 2009) and molecular detection and quantification methods (Murray et al., 2009; Penna et al., 2010; Nagahama et al., 2011; Perini et al., 2011; Accoroni et al., 2012; Pfannkuchen et al., 2012; Vandersea et al., 2012). However, before the full potential of molecular assays can be utilized, especially species-specific quantitative polymerase chain reaction assays ( $\mathrm{qPCR}$ ), problems inherent to sampling benthic harmful algal bloom (BHAB) dinoflagellates need to be addressed (GEOHAB, 2012). As a group, BHAB dinoflagellate species co-occur globally in shallow, tropical and subtropical environments where they are typically associated with benthic substrates. The most common substrates colonized by BHAB dinoflagellates include macroalgae, algal turf, seagrasses, 